[Article]

\title{
铈钵比对 $\mathrm{Ce}_{x} \mathrm{Ni}_{0.5} \mathrm{La}_{0.5-x} \mathrm{O}$ 系催化剂甘油氧化蒸汽重整制氢性能的影响
}

\author{
党成雄杨浩波余 皓* 王红娟彭 峰 \\ (华南理工大学化学与化工学院, 广州 510640)
}

\begin{abstract}
摘要: 利用共沉淀法制备了 $\mathrm{CeO}_{2}$ 和 $\mathrm{La}_{2} \mathrm{O}_{3}$ 复合载体的 $\mathrm{Ce}_{\times} \mathrm{Ni}_{0.5} \mathrm{La} \mathrm{L}_{0.5-\mathrm{x}} \mathrm{O}(\mathrm{CeNiLaO})$ 系催化剂, 在固定床反应器 中考察其甘油氧化蒸汽重整制氢( $(O S R G)$ 性能, 并采用 $X$ 射线衍射 $(X R D)$ 、程序升温还原 $\left(H_{2}-T P R\right)$ 、激光拉 曼光谱(Raman)、扫描电子显微镜(SEM)、透射电子显微镜(TEM)和 X射线光电子能谱(XPS)等手段对催化剂 进行表征分析。结果表明: $\mathrm{La}_{2} \mathrm{O}_{3}$ 能够有效地分散 $\mathrm{Ni}$ 颗粒, 减弱 $\mathrm{Ni}$ 颗粒在反应过程中的烧结, $\mathrm{CeO}_{2}$ 提供的 晶格氧能够消除催化剂表面的积碳, 同时 $\mathrm{La}$ 会部分进入 $\mathrm{Ce}$ 的晶格取代部分 $\mathrm{Ce} \mathrm{e}^{4+}$ 造成晶格畸变, 提高表面的 氧空穴数。 $\mathrm{La}_{2} \mathrm{O}_{3}$ 和 $\mathrm{CeO}_{2}$ 的共同作用有利于减弱 $\mathrm{Ni}$ 因为烧结和积碳引起的失活。在不同 $\mathrm{Ce} / \mathrm{La}$ 摩尔比的催化 剂中, $\mathrm{Ce}_{0.4 \mathrm{Ni} .5 \mathrm{La}} \mathrm{L}_{0.1} \mathrm{O}$ 表现出最好的催化活性, 并且该催化剂在长达 $210 \mathrm{~h}$ 的稳定性测试中, 甘油的转化率都 在 $95 \%$ 以上，气相产物中的氢气浓度达 $50 \%$ 。
\end{abstract}

关键词: 氧化铈; 氧化锞; 镍; 稳定性; 甘油; 制氢; 蒸汽重整

中图分类号: 0643

\section{$\mathrm{Ce}_{x} \mathrm{Ni}_{0.5} \mathrm{La}_{0.5-x} \mathrm{O}$ Catalysts for Hydrogen Production by Oxidative Steam Reforming of Glycerol: Influence of the Ce-to-La Ratio}

\author{
DANG Cheng-Xiong YANG Hao-Bo YU Hao* WANG Hong-Juan PENG Feng \\ (School of Chemistry and Chemical Engineering, South China University of Technology, Guangzhou 510640, P. R. China)
}

\begin{abstract}
Ce}_{x} \mathrm{Ni}_{0.5} \mathrm{La}_{0.5-x} \mathrm{O}(\mathrm{CeNiLaO})$ catalysts were synthesized using a Ce-La composite oxide as the carrier via co-precipitation. They were applied in the oxidative steam reforming of glycerol (OSRG) in a fixed-bed reactor. The catalysts were characterized by $\mathrm{X}$-ray diffraction (XRD), $\mathrm{H}_{2}$-temperature-programmed reduction $\left(\mathrm{H}_{2}\right.$-TPR), Raman spectroscopy, scanning electron microscopy (SEM), transmission electron microscopy (TEM), and Xray photoelectron spectroscopy (XPS). The results showed that $\mathrm{La}_{2} \mathrm{O}_{3}$ improved the dispersion of metallic $\mathrm{Ni}$ and suppressed the sintering of metallic Ni particles; the lattice oxygen of $\mathrm{CeO}_{2}$ inhibited and eliminated carbon deposition on the surface of the catalysts; and the substitution of some $\mathrm{La}^{3+}$ for $\mathrm{Ce}^{4+}$ ions induced a distortion of the lattice. The synergy of $\mathrm{La}_{2} \mathrm{O}_{3}$ and $\mathrm{CeO}_{2}$ lessened the deactivation caused by the sintering and coke deposition and improved the catalytic performance. Among the catalysts with different molar ratios of $\mathrm{Ce}$ to $\mathrm{La}$, $\mathrm{Ce}_{0.4} \mathrm{Ni}_{0.5} \mathrm{La}_{0.1} \mathrm{O}$ had the best catalytic activity. The conversion of glycerol remained above $95 \%$ after a $210 \mathrm{~h}$ stability test, while a gaseous reformate of about $50 \%$ hydrogen could be steadily produced.
\end{abstract}

Key Words: $\mathrm{CeO}_{2} ; \quad \mathrm{La}_{2} \mathrm{O}_{3} ; \quad \mathrm{Ni} ; \quad$ Stability; Glycerol; Hydrogen production; Steam reforming

\section{Introduction}

Hydrogen has been widely applied in fine chemicals and pe- troleum industries as a chemical raw material. Meanwhile, hydrogen is also considered as a potential clean and environmental

Received: January 4, 2016; Revised: March 15, 2016; Published on Web: March 16, 2016.

*Corresponding author. Email: yuhao@scut.edu.cn; Tel/Fax: + 86-20-87114916.

The project was supported by the National Natural Science Foundation of China (20176094), Program for New Century Excellent Talents in University of Ministry of Education of China (NCET-12-0190), and Pearl River Nova Program of Guangzhou City, China (2011J2200062). 国家自然科学基金(20176094), 教育部新世纪优秀人才支持计划项目(NCET-12-0190)和广州市珠江科技新星项目(2011J2200062)资助

(c) Editorial office of Acta Physico-Chimica Sinica 
friendly energy carrier, with high calorific value and zero pollution. At present, hydrogen is produced mainly by the steam reforming of natural gas in chemical industry. However, this process suffers from the unsustainable raw material and substantial carbon dioxide emissions. Renewable sources, especially those from biomass, are ideal feedstock to produce hydrogen, which makes this process sustainable and recycle $\mathrm{CO}_{2}$ back to grow more biomass ${ }^{1}$.

Glycerol is the major by-product from the transesterification of fatty acids to manufacture biodiesel, providing about $10 \%$ as glycerol. With the rapid growth of biodiesel production, glycerol has been increasingly produced in recent years. Thus, the application of glycerol has constrained the development of biodiesel industry ${ }^{2}$. Conversion of glycerol to hydrogen is one of the most attractive ways to make use of glycerol, which can either alleviate the oversupply of glycerol, or afford a renewable hydrogen production independent on fossil fuels.

Hydrogen can be produced from glycerol by the steam reforming (SRG) reaction with catalysts. Noble metal catalysts, such as $\mathrm{Pt}, \mathrm{Ru}, \mathrm{Rh}$, and $\mathrm{Ir}^{3-5}$, have been proved to be highly active for the SRG reaction, but are limited by the cost and resources. Compared with noble metal, Ni has attracted intensive research interests as a representative base metal catalyst ${ }^{6-9}$. Wu et al. ${ }^{6}$ fabricated the supported $\mathrm{Ni} / \mathrm{Al}_{2} \mathrm{O}_{3}$ catalyst with different $\mathrm{Ni}$ precursors. Under the optimum conditions, the yield of $\mathrm{H}_{2}$ was about $5.5 \mathrm{~mol} \cdot \mathrm{mol}^{-1}$ glycerol, approaching to the thermodynamic equilibrium value, $5.7 \mathrm{~mol} \cdot \mathrm{mol}^{-1}$. Wang et al. ${ }^{8}$ developed a Ni-MgAl catalyst, which showed an optimal performance with the conversion of glycerol up to $88.0 \%$ and the yield of $\mathrm{H}_{2}$ up to $78.5 \%$ at $650{ }^{\circ} \mathrm{C}$. However, Ni-based catalysts generally suffer from the rapid deactivation caused by sintering and coke deposition during the SRG reaction process ${ }^{10,11}$, which remains a major challenge for developing stable Ni-based catalysts.

It has been widely documented that an appropriate support is very important for the stability of Ni-based catalysts, because the supports may affect the metal dispersion and inhibit particle sintering and carbon formation ${ }^{12-15}$. Various oxides, including $\mathrm{La}_{2} \mathrm{O}_{3}, \mathrm{Al}_{2} \mathrm{O}_{3}, \mathrm{CeO}_{2}, \mathrm{ZrO}_{2}, \mathrm{SiO}_{2}$, and $\mathrm{MgO}$, have been investigated as supports of nickel ${ }^{6,12,15,16}$. $\mathrm{CeO}_{2}$ has excellent oxygen storagerelease capability by readily altering its oxidation states between $\mathrm{Ce}^{4+}$ and $\mathrm{Ce}^{3+}{ }^{17}$. This property can be used to remove coke deposition on the metal surface and suppress deactivation. Gong et $a l .{ }^{18}$ studied the effect of $\mathrm{CeO}_{2}$ on the performance of steam reforming of ethanol (SRE) over ceria-promoted Ni/SBA-15 catalysts and found that ceria promoter suppressed the coke formation on catalyst surfaces. Liu et al. ${ }^{19}$ also found that at temperatures above $327^{\circ} \mathrm{C}$, the lattice oxygen from ceria could eliminate the coke formed in the process of SRE. Our previous works ${ }^{3,11}$ show that $\mathrm{La}_{2} \mathrm{O}_{3}$ is beneficial for the redispersion of active metals, thereby slows the deactivation caused by sintering. Moreover, $\mathrm{La}_{2} \mathrm{O}_{3}$ has a strong interaction with nickel at high temperatures through forming La-Ni-O phases, which stabilize the nickel ${ }^{20,21}$. The incorporation of $\mathrm{La}_{2} \mathrm{O}_{3}$ could increase the dispersion of metallic $\mathrm{Ni}$ on $\mathrm{Ni} / \gamma-\mathrm{Al}_{2} \mathrm{O}_{3}$ and restrain the sintering of $\mathrm{Ni}$ particles, thus improve the stability of $\mathrm{Ni} / \gamma-\mathrm{Al}_{2} \mathrm{O}_{3}$ catalysts ${ }^{22}$. Both
$\mathrm{CeO}_{2}$ and $\mathrm{La}_{2} \mathrm{O}_{3}$ could improve the stability of Ni-based catalysts as supports. Ce and La composite oxide may further enhance the stability as a catalyst carrier ${ }^{20,23}$. Venezia et al. ${ }^{20}$ compared the catalytic behavior of $\mathrm{Ni}$ catalysts supported over $\mathrm{CeO}_{2}, \mathrm{La}_{2} \mathrm{O}_{3}$, and $\mathrm{CeO}_{2}-\mathrm{La}_{2} \mathrm{O}_{3}$ mixed oxide in the methane partial oxidation reaction. It was found that in the presence of mixed $\mathrm{CeO}_{2}-\mathrm{La}_{2} \mathrm{O}_{3}$ there was no coke formed. Arias et al. ${ }^{23}$ also found that, when $\mathrm{CeO}_{2}$ and $\mathrm{La}_{2} \mathrm{O}_{3}$ co-existed simultaneously, the catalysts displayed excellent stability. In this work, we synthesized $\mathrm{Ce}_{x} \mathrm{Ni}_{0.5} \mathrm{La}_{0.5-x} \mathrm{O}$ catalysts utilizing $\mathrm{Ce}$ and $\mathrm{La}$ composite oxide as a carrier via co-precipitation method and optimized the ratio of $\mathrm{CeO}_{2}$ to $\mathrm{La}_{2} \mathrm{O}_{3}$, to enhance the stability of Ni-based catalysts for the oxidative steam reforming of glycerol (OSRG) reaction.

\section{Experimental}

\subsection{Preparation of catalysts}

All the reagents are analytic pure and were purchased from Sinopharm Chemical Reagent Co., Ltd. Catalysts in this paper were synthesized via a co-precipitation method. Typically, $\mathrm{Ce}\left(\mathrm{NO}_{3}\right)_{3} \cdot 6 \mathrm{H}_{2} \mathrm{O}, \mathrm{Ni}\left(\mathrm{NO}_{3}\right)_{2} \cdot 6 \mathrm{H}_{2} \mathrm{O}$ and $\mathrm{La}\left(\mathrm{NO}_{3}\right)_{3} \cdot n \mathrm{H}_{2} \mathrm{O}$ were dissolved in deionized water with desired $\mathrm{Ce}^{2+} / \mathrm{La}^{3+}$ molar ratios and a $\mathrm{Ni}$ content of $50 \%$ (atomic fraction) in final products, then the $\mathrm{pH}$ of the solution was adjusted to 11 by adding triethylamine solution dropwise. After continuously stirring for $4 \mathrm{~h}$, the resulting white suspension was aged at room temperature for $2 \mathrm{~h}$. The precipitates were filtered and washed with deionized water, followed by drying at $110^{\circ} \mathrm{C}$ for $12 \mathrm{~h}$, and then calcined in air at $650{ }^{\circ} \mathrm{C}$ for $6 \mathrm{~h}$ to obtain the catalysts. The samples were denoted as $\mathrm{Ce}_{x} \mathrm{Ni}_{0.5} \mathrm{La}_{0.5-x} \mathrm{O}$, where $x$ represents the molar fraction of $\mathrm{Ce}$.

\subsection{Characterizations}

Specific surface areas of catalysts were measured by $\mathrm{N}_{2}$ adsorption at $-196{ }^{\circ} \mathrm{C}$ (ASAP 2010, Micromeritics, America). Before the measurements, the samples were degassed at $300{ }^{\circ} \mathrm{C}$ under vacuum overnight. Electron probe microanalysis (EPMA1600 , Shimadzu, Japan) was used to analyze the compositions of catalysts. Powder X-ray diffraction (XRD) measurements were performed in a Rigaku D/max- IIIAX diffractometer (Rigaku, Japan) using $\mathrm{Cu} K_{\alpha}$ radiation (operating at $40 \mathrm{kV}$ and $40 \mathrm{~mA}$ ). $\mathrm{H}_{2}$ temperature-programmed reduction $\left(\mathrm{H}_{2}\right.$-TPR) was employed to analyze the reduction behavior of the catalysts in a TP5080 adsorption instrument (Xian Quan, China) equipped with a thermal conductivity detector (TCD). The hydrogen consumption was measured by calculating the reduction peaks in the range of $100-$ $500{ }^{\circ} \mathrm{C}$ referenced to the reduction peak of $\mathrm{CuO}$ as a standard material. X-ray photoelectron spectroscopy (XPS) was performed in a Kratos Axis ultra (DLD) spectrometer (Kratos, England) equipped with an $\mathrm{Al} K_{\alpha} \mathrm{X}$-ray source. The binding energies were referenced to the $\mathrm{C} 1 s$ peak at $284.8 \mathrm{eV}$. Raman spectra were recorded on a LabRAM Aramis micro Raman spectrometer (Renishaw, England) with $633 \mathrm{~nm}$ wavelength laser and $2 \mu \mathrm{m}$ spot size. Transmission electron microscopy (TEM) measurements were performed in a TECNAI10 microscope (Philips-FEI, Holland) equipped with an INCA energy dispersive spectrometer operated 
at $200 \mathrm{kV}$. Specimens for TEM were prepared by ultrasonically suspending the sample in acetone and depositing a drop of the suspension onto a copper grid covered by amorphous carbon. SEM was performed in a LEO-1530VP microscope (LEO, German).

\subsection{Catalytic tests}

The OSRG reaction was carried out in a quartz tubular reactor with inner diameter of $8 \mathrm{~mm}$ and length of $280 \mathrm{~mm}$ to evaluate the catalytic activity of the catalysts. The configuration and operation of reactor had been described in our previous work ${ }^{24}$. Before reaction, $0.2 \mathrm{~g}$ catalyst was activated with $\mathrm{H}_{2}$ at a flow rate of 30 $\mathrm{mL} \cdot \mathrm{min}^{-1}$ at $500{ }^{\circ} \mathrm{C}$ for $20 \mathrm{~min}$, then heated the reactor to the desired temperature under $\mathrm{N}_{2}$ atmosphere. The gaseous products were analyzed by a gas chromatograph (He as carrier gas) equipped with a TCD and a flame ionization detector (FID). A TDX 01 column was used for $\mathrm{H}_{2}, \mathrm{CO}$ and $\mathrm{CO}_{2}$ analysis in TCD. $\mathrm{CH}_{4}$ and $\mathrm{C}_{2} \mathrm{H}_{4}$ were analyzed by FID with a packed column for analyzing transformer oil.

The glycerol conversion $\left(C_{\mathrm{gly}}\right)$ was calculated by

$$
C_{\mathrm{gly}}=\frac{\text { moles of carbon in gas products }}{3 \times F_{\text {in }}} \times 100 \%
$$

where $F_{\text {in }}$ represent moles of glycerol fed.

The selectivity of $\mathrm{H}_{2}$ was calculated by

$$
S_{\mathrm{H}_{2}}=\frac{\text { moles of } \mathrm{H}_{2} \text { produced }}{\text { moles of carbon in gas products }} \times \frac{3}{4} \times 100 \%
$$

The selectivities of carbon containing species $\left(\mathrm{CO}, \mathrm{CO}_{2}, \mathrm{CH}_{4}\right.$, and $\mathrm{C}_{2} \mathrm{H}_{4}$ ) in gas products were calculated by

$$
S_{i}=\frac{n \times \text { moles of } i}{\text { moles of carbon in gas products }} \times 100 \%
$$

where $n$ is the atom number of carbon in $i$ species.

\section{Results and discussion}

\subsection{Catalyst characterizations}

XRD patterns of fresh, reduced, and used catalysts with different $\mathrm{Ce} / \mathrm{La}$ ratios are presented in Fig. $1 . \mathrm{CeO}_{2}, \mathrm{NiO}, \mathrm{La}(\mathrm{OH})_{3}$ and some characteristic peaks from $\mathrm{LaNiO}_{3}$ were detected in the fresh catalysts. As the content of La increases, the characteristic peaks of $\mathrm{CeO}_{2}$ shift to low-angle region (see inset of Fig.1(a)). Meanwhile, there are no peaks from $\mathrm{La}$ species at lower $\mathrm{La}$ contents, indicating that some La ions may enter into the lattice of $\mathrm{CeO}_{2}$ and induce a lattice distortion. In addition, the peaks of $\mathrm{NiO}$ gradually broaden with the introduction of $\mathrm{La}$, proving that $\mathrm{La}_{2} \mathrm{O}_{3}$ could increase the dispersion of $\mathrm{NiO}$ particles. The appearance of $\mathrm{La}(\mathrm{OH})_{3}$ may be resulted from the reaction between La species and moisture. After $\mathrm{H}_{2}$ reduction at $500{ }^{\circ} \mathrm{C}, \mathrm{NiO}$ turns into $\mathrm{Ni}$ completely (Fig.1(b)). $\mathrm{La}(\mathrm{OH})_{3}$ would turn into $\mathrm{La}_{2} \mathrm{O}_{2} \mathrm{CO}_{3}$ after the OSRG reaction (Fig.1(c)), probably through the decomposition of $\mathrm{La}(\mathrm{OH})_{3}$ to $\mathrm{La}_{2} \mathrm{O}_{3}$ and the carbonization of $\mathrm{La}_{2} \mathrm{O}_{3}$ to $\mathrm{La}_{2} \mathrm{O}_{2} \mathrm{CO}_{3}{ }^{3,24}$.

Table 1 summarizes the textual properties and crystallite sizes of fresh, reduced, and used catalysts with different $\mathrm{Ce} / \mathrm{La}$ molar ratios. The Scherrer equation was used to estimate the mean crystallite size from the (111) diffraction peak of $\mathrm{Ni}$ or the (012) peak of $\mathrm{NiO}$. The crystallite sizes of $\mathrm{NiO}$ and $\mathrm{Ni}$ decreased greatly after incorporating $\mathrm{La}$, indicating the dispersion effect of $\mathrm{La}_{2} \mathrm{O}_{3}$ on nickel. The smallest $\mathrm{Ni}$ crystallite size is reached over the
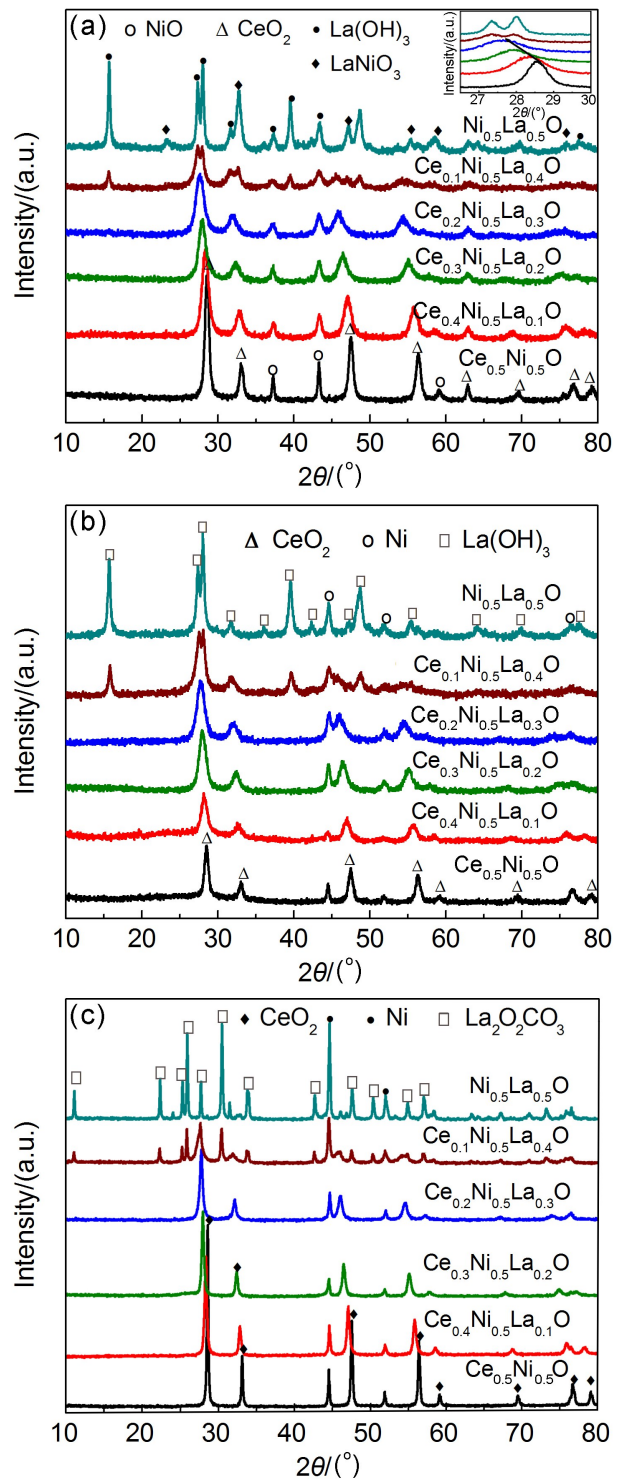

Fig.1 XRD patterns of (a) fresh, (b) reduced, and (c) used $\mathrm{Ce}_{x} \mathrm{Ni}_{0.5} \mathrm{La}_{0.5-x} \mathrm{O}$ catalysts

Inset shows the characteristic peaks of $\mathrm{CeO}_{2}$ shifting to low-angle region.

$\mathrm{Ce}_{0.4} \mathrm{Ni}_{0.5} \mathrm{La}_{0.1} \mathrm{O}$ catalyst. In addition, the $\mathrm{Ce}_{0.4} \mathrm{Ni}_{0.5} \mathrm{La}_{0.1} \mathrm{O}$ also shows the highest specific surface area and pore volume. For all the catalysts, the sintering of $\mathrm{Ni}$ can be observed after the OSRG reaction, indicated by the increasing size of Ni particles. Nevertheless, the sintering of $\mathrm{Ni}$ particles would be somewhat retarded over the La-containing samples, indicated by the less increase of Ni particle size after the OSRG reaction, suggesting the improved thermal stability of catalyst ${ }^{22}$.

The TPR curves of $\mathrm{Ce}_{x} \mathrm{Ni}_{0.5} \mathrm{La}_{0.5-x} \mathrm{O}$ catalysts are shown in Fig.2. The weak reduction peak below $300{ }^{\circ} \mathrm{C}$ could be ascribed to the reduction of highly dispersed $\mathrm{Ni}$ species on surfaces ${ }^{25}$. The two overlapping peaks in the range of $300-500{ }^{\circ} \mathrm{C}$ could be assigned as the reduction of $\mathrm{Ni}^{2+}$ which has weak and strong interaction with support, respectively. The high temperature reduction peak of $\mathrm{Ce}_{0.5} \mathrm{Ni}_{0.5} \mathrm{O}$ at $800{ }^{\circ} \mathrm{C}$ is from the reduction of $\mathrm{Ce}^{4+}$ to $\mathrm{Ce}^{3+26,27}$, which is absent for other catalysts, probably due to the stronger 
Table 1 Compositions and physical properties of the fresh, reduced, and used $\mathrm{Ce}_{x} \mathrm{Ni}_{0.5} \mathrm{La}_{0.5-x} \mathrm{O}$ catalysts

\begin{tabular}{|c|c|c|c|c|c|c|c|c|c|}
\hline \multirow{2}{*}{ Catalyst } & \multicolumn{4}{|c|}{ Composition $/ \%$} & \multicolumn{3}{|c|}{ Size/nm } & \multirow{2}{*}{$\begin{array}{c}\text { Specific } \\
\text { surface } \operatorname{area} /\left(\mathrm{m}^{2} \cdot \mathrm{g}^{-1}\right)\end{array}$} & \multirow{2}{*}{$\begin{array}{l}\text { Pore volume } \\
\left(\mathrm{cm}^{3} \cdot \mathrm{g}^{-1}\right)\end{array}$} \\
\hline & $\mathrm{Ce}$ & $\mathrm{Ni}$ & $\mathrm{La}$ & $\mathrm{O}$ & fresh $\left(\mathrm{NiO}^{b}\right)$ & reduced $\left(\mathrm{Ni}^{\mathrm{b}}\right)$ & OSRG used $\left(\mathrm{Ni}^{\mathrm{b}}\right)$ & & \\
\hline $\mathrm{Ce}_{0.5} \mathrm{Ni}_{0.5} \mathrm{O}$ & 25.09 & 25.71 & 0.00 & 49.20 & 24.2 & 20.7 & 42.4 & 30.7 & 0.113 \\
\hline $\mathrm{Ce}_{0.4} \mathrm{Ni}_{0.5} \mathrm{La}_{0.1} \mathrm{O}$ & 19.40 & 25.69 & 4.55 & 50.36 & 13.2 & 12.9 & 35.4 & 42.8 & 0.160 \\
\hline $\mathrm{Ce}_{0.3} \mathrm{Ni}_{0.5} \mathrm{La}_{0.2} \mathrm{O}$ & 15.34 & 30.31 & 8.20 & 46.15 & 12.3 & 13.9 & 34.0 & 21.3 & 0.121 \\
\hline $\mathrm{Ce}_{0.2} \mathrm{Ni}_{0.5} \mathrm{La}_{0.3} \mathrm{O}$ & 10.30 & 27.53 & 14.84 & 47.33 & 9.2 & 13.0 & 32.7 & 10.7 & 0.079 \\
\hline $\mathrm{Ce}_{0.1} \mathrm{Ni}_{0.5} \mathrm{La}_{0.4} \mathrm{O}$ & 4.72 & 25.57 & 20.32 & 49.39 & 7.4 & 14.6 & 25.7 & 16.0 & 0.115 \\
\hline $\mathrm{Ni}_{0.5} \mathrm{La}_{0.5} \mathrm{O}$ & 0.00 & 23.09 & 23.26 & 53.66 & 14.1 & 15.2 & 25.6 & 13.4 & 0.058 \\
\hline
\end{tabular}

reaction conditions: $T=650^{\circ} \mathrm{C}$, carbon-to-oxygen molar ratio $=1$, steam-to-carbon molar ratio $=4$, gas hourly space velocity $(\mathrm{GHSV})=120000 \mathrm{~h}^{-1}, t=5 \mathrm{~h}$. atomic fraction, measured by EPMA with fresh catalysts. 'crystallite sizes calculated by Scherrer equation.

metal-support interaction (MSI) over the mixed oxides. The strongest MSI is achieved on the composition of $\mathrm{Ce}_{0.4} \mathrm{Ni}_{0.5} \mathrm{La}_{0.1} \mathrm{O}$, evidenced by the highest reduction peak temperature. Considering the refractory nature of $\mathrm{La}$, the minor peaks of $\mathrm{Ni}_{0.5} \mathrm{La}_{0.5} \mathrm{O}$ in the range from 500 to $650{ }^{\circ} \mathrm{C}$ can be attributed to the decomposition of $\mathrm{La}_{2} \mathrm{O}_{2} \mathrm{CO}_{3}{ }^{3}$. The $\mathrm{H}_{2}$ comsuptions were calculated by integrating the peaks from room temperature (r.t.) to $500{ }^{\circ} \mathrm{C}$. Assuming $\mathrm{Ni}^{2+}$

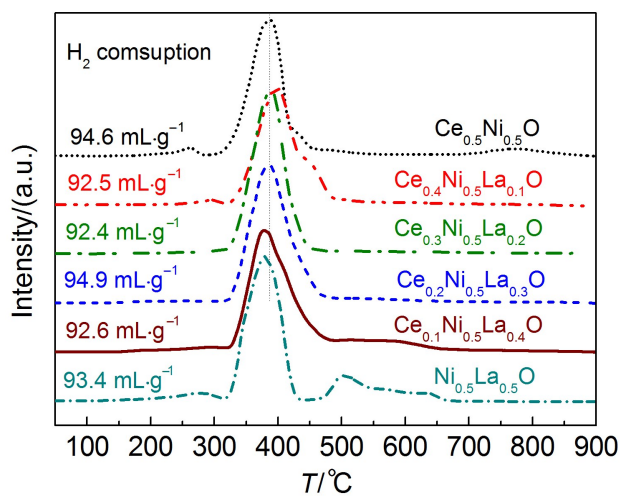

Fig.2 $\mathrm{H}_{2}$-TPR profiles of $\mathrm{Ce}_{x} \mathrm{Ni}_{0.5} \mathrm{La}_{0.5-x} \mathrm{O}$ catalysts as the reducible species, the $\mathrm{H}_{2}$ comsuptions are very close to the theoretical values of $\mathrm{Ce}_{x} \mathrm{Ni}_{0.5} \mathrm{La}_{0.5-x} \mathrm{O}$ (from 90.8 to $94.3 \mathrm{~mL} \cdot \mathrm{g}^{-1}$ ).

As shown in Fig.3, the fresh $\mathrm{Ce}_{x} \mathrm{Ni}_{0.5} \mathrm{La}_{0.5-x} \mathrm{O}$ catalysts display similar porous structures composed of aggregated particles. $\mathrm{H}_{2}-$ reduction has little effect on the catalyst morphology. Ni crystallites can be observed in TEM images (Fig.4). Compared with $\mathrm{Ce}_{0.5} \mathrm{Ni}_{0.5} \mathrm{O}$, the $\mathrm{Ce}_{0.4} \mathrm{Ni}_{0.5} \mathrm{La}_{0.1} \mathrm{O}$ is comprised of smaller particles, being consistent with the results of XRD. It should be noticed that the lattice spacing of the (200) planes of $\mathrm{CeO}_{2}$ in the $\mathrm{Ce}_{0.4} \mathrm{Ni}_{0.5} \mathrm{La}_{0.1} \mathrm{O}$ is $0.284 \mathrm{~nm}$ (inset of Fig.4(b)), which is larger than pure $\mathrm{CeO}_{2}$ (0.2706 nm, PDF\#43-1002), indicating the substitution of $\mathrm{La}$ for $\mathrm{Ce}$ ions as revealed by $\mathrm{XRD}$ results. The formation of CeLa-O mixed oxides is also supported by the absence of any La species in the HR-TEM observation.

Fig. 5 shows the Raman spectra of $\mathrm{Ce}_{x} \mathrm{Ni}_{0.5} \mathrm{La}_{0.5-x} \mathrm{O}$ catalysts and pure $\mathrm{CeO}_{2}$. Because of the intense fluorescent effect of La species on Raman spectra, the measurements were conducted for the samples with $x<0.3$ to avoid the excessive amounts of La. The band at $464 \mathrm{~cm}^{-1}$ could be ascribed to the $F_{2 \mathrm{~g}}$ vibration mode of fluorite structure of $\mathrm{CeO}_{2}{ }^{28}$. When the amount of $\mathrm{La}$ increased, the band shifted to lower wave numbers, which may be caused by the

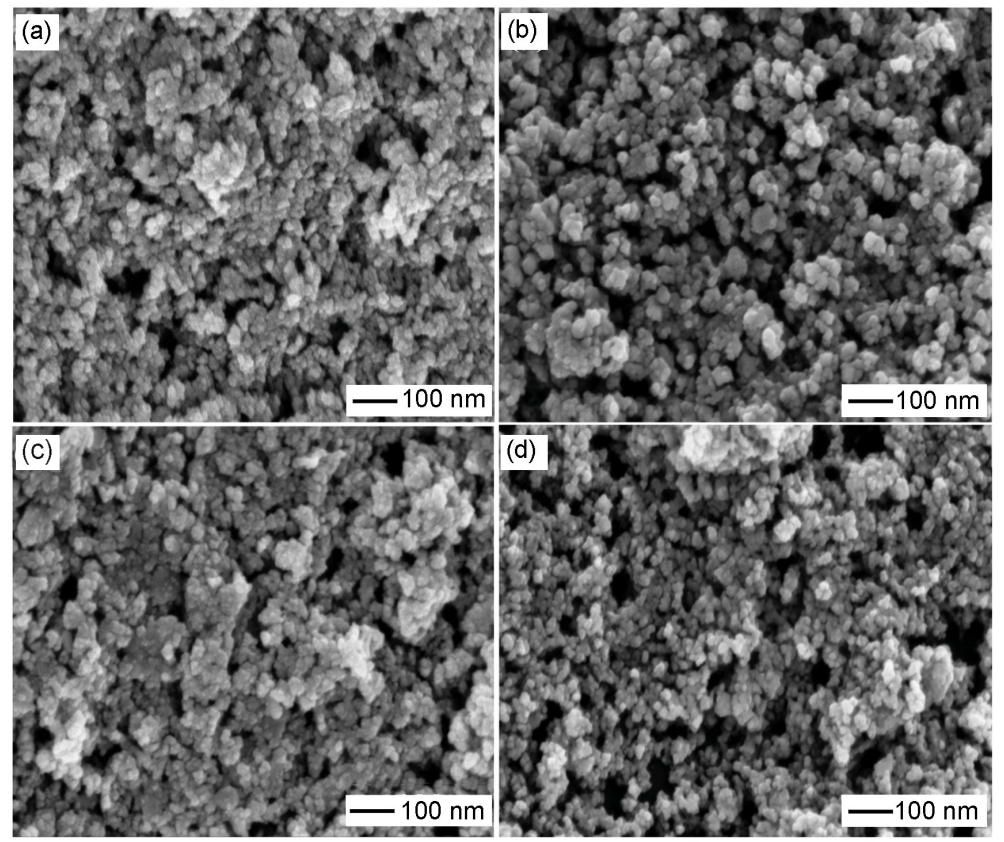

Fig.3 SEM images of fresh (a) and reduced (b) $\mathrm{Ce}_{0.5} \mathrm{Ni}_{0.5} \mathrm{O}$, fresh (c) and reduced (d) $\mathrm{Ce}_{0.4} \mathrm{Ni}_{0.5} \mathrm{La}_{0.1} \mathrm{O}$ catalysts 


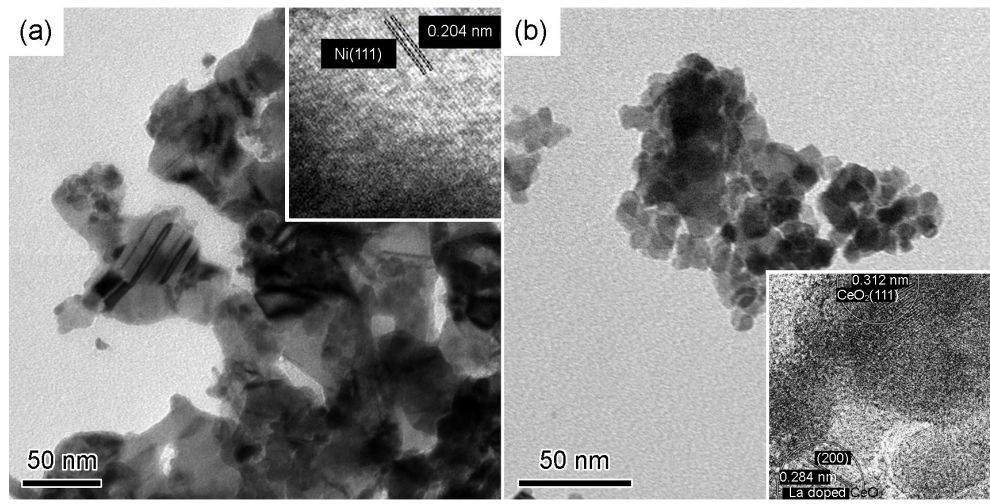

Fig.4 TEM images of reduced (a) $\mathrm{Ce}_{0.5} \mathrm{Ni}_{0.5} \mathrm{O}$ and (b) $\mathrm{Ce}_{0.4} \mathrm{Ni}_{0.5} \mathrm{La}_{0.1} \mathrm{O}$ and HR-TEM images of used $\mathrm{Ce}_{0.4} \mathrm{Ni}_{0.5} \mathrm{La}_{0.1} \mathrm{O}$ after OSRG reaction reaction conditions: $T=650^{\circ} \mathrm{C}$, carbon-to-oxygen molar ratio $=1$, steam-to-carbon molar ratio $=4, \mathrm{GHSV}=60000 \mathrm{~h}^{-1}, t=210 \mathrm{~h}$

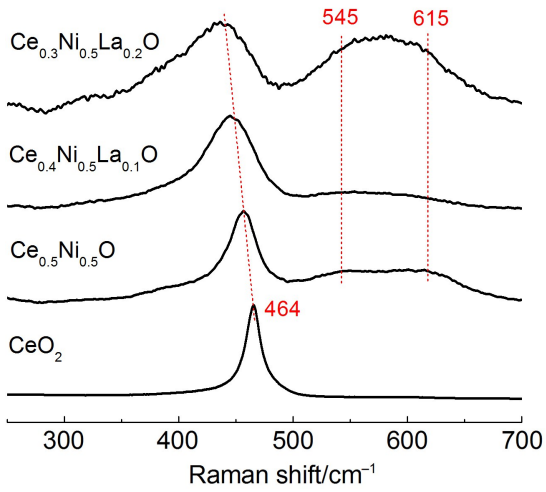

Fig.5 Raman spectra of pure $\mathrm{CeO}_{2}$ and $\mathrm{Ce}_{x} \mathrm{Ni}_{0.5} \mathrm{La}_{0.5-x} \mathrm{O}$ catalysts

incorporation of heteroatom ions into the lattice of $\mathrm{CeO}_{2}{ }^{29}$. Herein, we conclude that the shift probably stems from the incorporation of $\mathrm{La}$ or $\mathrm{Ni}$ as revealed by aforementioned analysis. Two overlapping bands in the range of $500-650 \mathrm{~cm}^{-1}$ can be observed for all the $\mathrm{Ce}_{x} \mathrm{Ni}_{0.5} \mathrm{La}_{0.5-x} \mathrm{O}$ catalysts. The band at $545 \mathrm{~cm}^{-1}$ could be attributed to the $\mathrm{O}^{2-}$ vacancy on catalyst surfaces, and the one at $615 \mathrm{~cm}^{-1}$ could be ascribed to the vacancy-interstitial oxygen defects in ceria ${ }^{30}$. As shown in Fig.5, either La or Ni would create oxygen vacancies on catalyst surfaces, and the strong intensity of the defect-related bands of $\mathrm{Ce}_{0.3} \mathrm{Ni}_{0.5} \mathrm{La}_{0.2} \mathrm{O}$ suggests that the amount of oxygen vacancies could be tuned by catalyst composition.

Fig. 6 reports the XPS spectra of $\mathrm{Ce}_{x} \mathrm{Ni}_{0.5} \mathrm{La}_{0.5-x} \mathrm{O}$ in the $\mathrm{O} 1 s$ binding energy (BE) regions. The XPS spectra exhibit similar broad doublet peaks in all catalysts. The lower BEs can be assigned to lattice oxygen (labeled as OI) and the BEs with higher

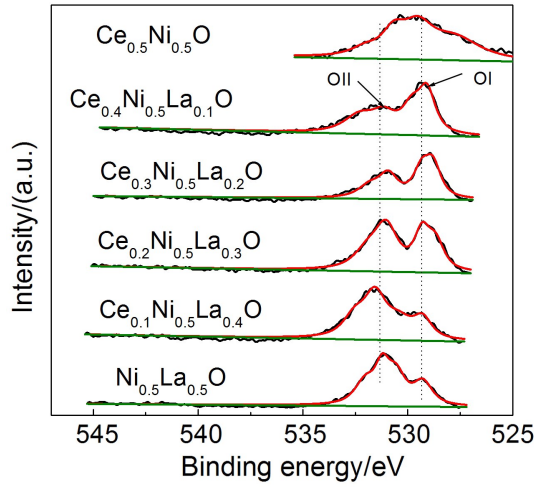

Fig.6 O $1 s$ XPS spectra of fresh $\mathrm{Ce}_{x} \mathrm{Ni}_{0.5} \mathrm{La}_{0.5-x} \mathrm{O}$ catalysts

values are attributed to other surface oxygen species (labeled as $\mathrm{OII})^{31-33}$. The surface oxygens (OII) increase with the incorporation of $\mathrm{La}^{34}$ because of the formation of $\mathrm{La}(\mathrm{OH})_{3}$ or $\mathrm{La}_{2} \mathrm{O}_{2} \mathrm{CO}_{3}$, as revealed by XRD, but, the amount of lattice oxygen changes in a contrary tendency. The results indicate La would increase the amount of OII and Ce could improve OI. Meanwhile, the shift of $\mathrm{BE}$ of OI toward lower values with incorporating $\mathrm{La}^{3+}$, see the cases $x=0.1,0.2,0.3$, indicates that La ions have entered into the lattice of $\mathrm{CeO}_{2}{ }^{32}$, which is agreement with the analysis of XRD, HR-TEM, and Raman spectroscopy.

\subsection{Catalytic performance of $\mathrm{Ce}_{x} \mathrm{Ni}_{0.5} \mathrm{La}_{0.5-x} \mathrm{O}$ catalysts}

OSRG and SRG reactions were performed under the optimized conditions established in our previous work ${ }^{3}$. Table 2 compares their catalytic performances. In $\mathrm{SRG}, \mathrm{Ce}_{0.4} \mathrm{Ni}_{0.5} \mathrm{La}_{0.1} \mathrm{O}$ showed the best activity, indicated by the highest conversion of glycerol and

Table 2 Catalytic performance of $\mathrm{Ce}_{x} \mathrm{Ni}_{0.5} \mathrm{La}_{0.5_{-}} \mathrm{O}$ catalysts in SRG and oxidative SRG (OSRG)

\begin{tabular}{|c|c|c|c|c|c|c|c|c|c|c|c|c|}
\hline \multirow{2}{*}{ Catalyst } & \multicolumn{6}{|c|}{$\mathrm{OSRG}^{\mathrm{a}}$} & \multicolumn{6}{|c|}{$\mathrm{SRG}^{\mathrm{b}}$} \\
\hline & $C_{\mathrm{gly}} / \%$ & $S_{\mathrm{CO}} / \%$ & $S_{\mathrm{CO}_{2}} / \%$ & $\mathrm{~S}_{\mathrm{CH}_{4}} / \%$ & $S_{\mathrm{C}_{2} \mathrm{H}_{4}} / \%$ & $\mathrm{STY}_{\mathrm{H}_{2}}{ }^{\mathrm{c}} /\left(\mathrm{L} \cdot \mathrm{g}^{-1} \cdot \mathrm{h}^{-1}\right)$ & $C_{\text {gly }} / \%$ & $S_{\mathrm{CO}} / \%$ & $S_{\mathrm{CO}_{2}} / \%$ & $S_{\mathrm{CH}_{4}} / \%$ & $S_{\mathrm{C}_{2} \mathrm{H}_{4}} / \%$ & $\operatorname{STY}_{\mathrm{H}_{2}}{ }^{\mathrm{c}} /\left(\mathrm{L} \cdot \mathrm{g}^{-1} \cdot \mathrm{h}^{-1}\right)$ \\
\hline $\mathrm{Ce}_{0.5} \mathrm{Ni}_{0.5} \mathrm{O}$ & 99.8 & 21.0 & 78.7 & 0.37 & - & 12.3 & 84.3 & 35.3 & 55.5 & 4.1 & 5.08 & 18.4 \\
\hline $\mathrm{Ce}_{0.4} \mathrm{Ni}_{0.5} \mathrm{La}_{0.1} \mathrm{O}$ & 100 & 24.7 & 75.1 & 0.24 & - & 13.4 & 98.9 & 32.2 & 60.3 & 6.8 & 0.68 & 21.6 \\
\hline $\mathrm{Ce}_{0.3} \mathrm{Ni}_{0.5} \mathrm{La}_{0.2} \mathrm{O}$ & 99.5 & 20.9 & 78.6 & 0.50 & - & 12.4 & 87.8 & 34.0 & 59.3 & 4.6 & 2.07 & 19.4 \\
\hline $\mathrm{Ce}_{0.2} \mathrm{Ni}_{0.5} \mathrm{La}_{0.3} \mathrm{O}$ & 97.7 & 23.2 & 75.5 & 1.38 & - & 12.7 & 55.7 & 38.4 & 43.5 & 2.7 & 15.31 & 9.5 \\
\hline $\mathrm{Ce}_{0.1} \mathrm{Ni}_{0.5} \mathrm{La}_{0.4} \mathrm{O}$ & 97.6 & 25.0 & 73.8 & 1.18 & - & 10.2 & 40.0 & 40.0 & 35.3 & 2.9 & 21.80 & 5.3 \\
\hline $\mathrm{Ni}_{0.5} \mathrm{La}_{0.5} \mathrm{O}$ & 94.8 & 24.9 & 74.1 & 1.08 & - & 9.5 & 58.9 & 36.0 & 45.7 & 3.1 & 15.26 & 9.6 \\
\hline
\end{tabular}

areaction conditions: $T=650^{\circ} \mathrm{C}$, steam-to-carbon molar ratio $=2$, carbon-to-oxygen molar ratio $=1, \mathrm{GHSV}=120000 \mathrm{~h}^{-1}, t=5 \mathrm{~h} ;{ }^{b}$ reaction conditions: $T=650{ }^{\circ} \mathrm{C}$,

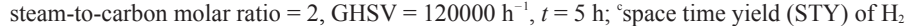




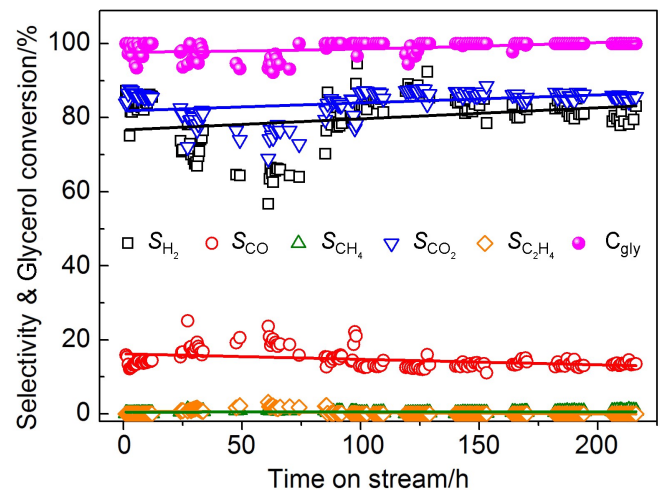

Fig.7 Stability test of $\mathrm{Ce}_{0.4} \mathrm{Ni}_{0.5} \mathrm{La}_{0.1} \mathrm{O}$ in the OSRG reaction reaction conditions: $T=650{ }^{\circ} \mathrm{C}$, carbon-to-oxygen molar ratio $=1$, steam-to-carbon molar ratio $=4, \mathrm{GHSV}=60000 \mathrm{~h}^{-1}$

much lower selectivity of $\mathrm{C}_{2} \mathrm{H}_{4}$. Since $\mathrm{C}_{2} \mathrm{H}_{4}$ is a typical precursor of polymerized condensation resulting in carbon deposition, the lower selectivity of $\mathrm{C}_{2} \mathrm{H}_{4}$ links to the better stability against coking. Introduction of oxygen could relieve the deactivation by coking and improve the thermodynamic equilibrium conversion of reaction system ${ }^{3}$. Therefore, all the catalysts displayed the higher activity in OSRG. Meanwhile, $\mathrm{Ce}_{0.4} \mathrm{Ni}_{0.5} \mathrm{La}_{0.1} \mathrm{O}$ still performed the best. It is worth pointing out that $\mathrm{Ce}_{0.4} \mathrm{Ni}_{0.5} \mathrm{La}_{0.1} \mathrm{O}$ also presented very high yield of $\mathrm{H}_{2}$. In the case of OSRG, the $\mathrm{H}_{2}$ STY value could reach $13.4 \mathrm{~L} \cdot \mathrm{g}^{-1} \cdot \mathrm{h}^{-1}$. In the case of $\mathrm{SRG}$, a very high STY value could be reached at $21.6 \mathrm{~L} \cdot \mathrm{g}^{-1} \cdot \mathrm{h}^{-1}$, which is much higher than most of literature ${ }^{35}$. According to the results of catalyst characterizations, two reasons may be responsible for the high performance of $\mathrm{Ce}_{0.4} \mathrm{Ni}_{0.5} \mathrm{La}_{0.1} \mathrm{O}$, detailed as follows: (i) the existence of $\mathrm{La}_{2} \mathrm{O}_{3}$ could increase the dispersity of metallic $\mathrm{Ni}$ and enhance the MSI, thus suppress the sintering of metallic Ni particles; (ii) the lattice oxygen from $\mathrm{CeO}_{2}$ could inhibit the coke formation and facilitate the removal of coke simultaneously on the catalyst surfaces. The substitution of $\mathrm{La}$ for $\mathrm{Ce}$ would improve the amount of the surface oxygen. However, the excessive La would decrease the activity due to the decreased lattice oxygen, specific surface area and pore volume. This has also been proved by Xu et $a l^{22}$.

The $\mathrm{Ce}_{0.4} \mathrm{Ni}_{0.5} \mathrm{La}_{0.1} \mathrm{O}$ catalyst was subjected to a long-term stability test for $210 \mathrm{~h}$. As shown in Fig. $7, \mathrm{Ce}_{0.4} \mathrm{Ni}_{0.5} \mathrm{La}_{0.1} \mathrm{O}$ showed an excellent stability, indicated by the high conversion of glycerol above $95 \%$ and the steady production of $\mathrm{H}_{2}$-enriched gas with about $85 \% \mathrm{H}_{2}$ selectivity ( $\sim 50 \%$ purity) during the $210 \mathrm{~h}$ time on stream. At the meantime, the concentrations of $\mathrm{CH}_{4}$ and $\mathrm{C}_{2} \mathrm{H}_{4}$ stayed very low (less than $0.3 \%$ ). The aforementioned results demonstrated that the $\mathrm{Ce}_{0.4} \mathrm{Ni}_{0.5} \mathrm{La}_{0.1} \mathrm{O}$ catalyst can be used as an efficient and stable material for reforming glycerol to produce hydrogen-enriched gas.

\section{Conclusions}

We synthesized $\mathrm{Ce}_{x} \mathrm{Ni}_{0.5} \mathrm{La}_{0.5-x} \mathrm{O}$ catalysts utilizing $\mathrm{Ce}$ and $\mathrm{La}$ composite oxides as carrier via co-precipitation method and studied the effect of $\mathrm{Ce}$ to La ratios on the catalytic performance in reforming glycerol for hydrogen production. Catalyst characterizations indicate that $\mathrm{La}_{2} \mathrm{O}_{3}$ could disperse and stabilize $\mathrm{Ni}$ particles. The substitution of $\mathrm{La}$ for $\mathrm{Ce}$ would increase the amount of the oxygen species on catalyst surfaces. The synergy of $\mathrm{La}_{2} \mathrm{O}_{3}$ and $\mathrm{CeO}_{2}$ could prevent the Ni-based catalyst from deactivation caused by the sintering and coke deposition. $\mathrm{Ce}_{0.4} \mathrm{Ni}_{0.5} \mathrm{La}_{0.1} \mathrm{O}$ was the optimal catalyst, because of the highest lattice oxygen concentration, surface area, the strong MSI and the smallest Ni particle size. The conversion of glycerol retained no change above $95 \%$ and the $\mathrm{H}_{2}$ concentration was maintained around $50 \%$ in a long-term stability test for $210 \mathrm{~h}$. Our work suggests the Ce-La composite is promising as a support of Ni-based catalysts to achieve a highly efficient and stable catalyst for the OSRG reaction.

\section{References}

(1) Yang, G. X.; Lai, C. F.; Li, S.; Yu, H.; Peng, F. Industrial Catal. 2010, 18, 1. [杨光星, 赖超凤, 李 爽, 余 皓, 彭 峰. 工业催 化, 2010, 18, 1.]

(2) Dou, B. L.; Chen, H. S. Chem. Ind. Eng. Prog. 2011, 30, 967. [豆斌林, 陈海生. 化工进展, 2011, 30, 967.]

(3) Huang, X. Y.; Dang, C. X.; Yu, H.; Wang, H. J.; Peng, F. ACS Catal. 2015, 5, 1155. doi: 10.1021/cs5014305

(4) Slinn, M.; Kendall, K.; Mallon, C.; Andrews, J. Bioresource Technol. 2008, 99, 5851. doi: 10.1016/j.biortech.2007.10.003

(5) Hirai, T.; Ikenaga, N.; Miyake, T.; Suzuki, T. Energy \& Fuels 2005, 19, 1761. doi: 10.1021/ef050121q

(6) Wu, G. W.; Zhang, C. X.; Li, S. R.; Han, Z. P.; Wang, T.; Ma, X. B.; Gong, J. L. ACS Sustain. Chem. Eng. 2013, 1, 1052. doi: $10.1021 / \mathrm{sc} 400123 \mathrm{f}$

(7) Wu, G. W.; Li, S. R.; Zhang, C. X.; Wang, T.; Gong, J. L. Appl. Catal. B 2014, 144, 277. doi: 10.1016/j.apcatb.2013.07.028

(8) Wang, C.; Dou, B. L.; Chen, H. S.; Song, Y. C.; Xu, Y. J.; Du, X.; Luo, T, T.; Tan, C. Q. Chem. Eng. J. 2013, 220, 133. doi: 10.1016/j.cej.2013.01.050

(9) Li, L.; Guo, W. L.; Li, J. L.; Dai, X.; Zhu, H.; Wang, X. B.; Deng, X. Z. Chem. Ind. Eng. Prog. 2013, 32, 122. [李 否, 郭瓦 力, 李俊磊, 戴 㕵, 朱 虹, 王晓冰, 邓信忠. 化工进展, 2013, 32, 122.]

(10) Ma, H. Y.; Zeng, L.; Tian, H.; Li, D.; Wang, X.; Li, X. Y.; Gong, J. L. Appl. Catal. B 2016, 181, 321. doi: 10.1016/j. apcatb.2015.08.019

(11) Chen, H. Q.; Yu, H.; Peng, F.; Yang, G. X.; Wang, H. J.; Yang, J.; Tang, Y. Chem. Eng. J. 2010, 160, 333. doi: 10.1016/j. cej.2010.03.054

(12) Yang, Y.; Wu, F.; Ma, J. X. Chin. J. Catal. 2005, 26, 131. [杨 宇, 吴 绯, 马建新. 催化学报, 2005, 26, 131.]

(13) Jiang, H. T.; Hua, W.; Ji, J. B. Prog. Chem. 2013, 25, 859. [姜洪 涛, 华 炜, 计建炳. 化学进展, 2013, 25, 859.]

(14) Srinivas, D.; Satyanarayana, C. V. V.; Potdar, H. S.; Ratnasamy, P. Appl. Catal. A 2003, 246, 323. doi: 10.1016/S0926-860X(03) 
$00085-1$

(15) Nichele, V.; Signoretto, M.; Menwgazzo, F.; Gallo, A.; Santo, V. D.; Cruciani, G.; Cerrato, G. Appl. Catal. B 2012, 111-112, 225. doi: 10.1016/j.apcatb.2011.10.003

(16) Adhikari, S.; Fernando, S. D.; Haryanto, A. Renew. Energy 2008, 33, 1097. doi: 10.1016/j.renene.2007.09.005

(17) Soykal, I. I.; Sohn, H.; Singh, D.; Miller, J. T.; Ozkan, U. S. ACS Catal. 2014, 4, 585. doi: 10.1021/cs400908h

(18) Li, D.; Zeng, L.; Li, X. Y.; Wang, X.; Ma, H. Y.; Assabumrungrat, S.; Gong, J. L. Appl. Catal. B 2015, 176-177, 532. doi: 10.1016/j.apcatb.2015.04.020

(19) Liu, Z. Y.; Duchon, T.; Wang, H. R.; Peterson, E. W.; Zhou, Y. H.; Luo, S.; Zhou, J.; Matolin, V.; Stacchiola, D. J.; Rodriguez, J. A.; Senanayake, S. D. J. Phys. Chem. C 2015, 119, 18248. doi: 10.1021/acs.jpcc.5b04310

(20) Pantaleo, G.; Parola, V. L.; Deganello, F.; Calatozzo, P.; Bal, R.; Venezia, A. M. Appl. Catal. B 2015, 164, 135. doi: 10.1016/j. apcatb.2014.09.011

(21) Tsipouriari, V. A.; Verykios, X. E. J. Catal. 1998, 179, 292. doi: 10.1006/jcat.1998.2183

(22) Xu, J. K.; Ren, K. W.; Wang, X. L.; Zhou, W.; Pan, X. M.; Ma, J. X. Acta Phys. -Chim. Sin. 2008, 24, 1568. [徐军科, 任克威, 王晓蕾, 周 伟, 潘相敏, 马建新. 物理化学学报, 2008, 24, 1568.] doi: 10.3866/PKU.WHXB20080907

(23) Miletić, N.; Izquierdo, U.; Obregón, I.; Bizkarra, K.; Agirrezabal-Telleria, I.; Bario, L. V.; Arias, P. L. Catal. Sci. Technol. 2015, 5, 1704. doi: 10.1039/c4cy01438c

(24) Yang, G. X.; Yu, H.; Huang, X. Y.; Peng, F.; Wang, H. J. Appl. Catal. B 2012, 127, 89. doi: 10.1016/j.apcatb.2012.08.003
(25) Jalowiecki-Duhamel, L.; Zarrou, H.; D'Huysser, A. Int. J. Hydrog. Energy 2008, 33, 5527. doi: 10.1016/j. ijhydene.2008.07.031

(26) Xu, S.; Wang, X. L. Fuel 2005, 84, 563. doi: 10.1016/j. fuel.2004.10.008

(27) Fornasiero, P.; Dimonte, R.; Rao, G. R.; Kaspar, J.; Meriani, S.; Trovarelli, A.; Graziani, M. J. Catal. 1995, 151, 168. doi: $10.1006 /$ jcat.1995.1019

(28) Reddy, B. M.; Khan, A.; Lakshmanan, P.; Aouine, M.; Loridant, S.; Volta, J. C. J. Phys. Chem. B 2005, 109, 3355. doi: 10.1021/ jp045193h

(29) Liu, Y. M.; Wang, L. C.; Chen, M.; Xu, J.; Cao, Y.; He, H. Y.; Fan, K. N. Catal. Lett. 2009, 130, 350. doi: 10.1007/s10562-0099977-z

(30) Wang, S. Y.; Li, N.; Luo, L. F.; Huang, W. X.; Pu, Z. Y.; Wang, Y. J.; Hu, G. S.; Luo, M. F.; Lu, J. Q. App. Catal. B 2014, 144, 325. doi: $10.1016 /$ j.apcatb.2013.07.037

(31) Piumetti, M.; Bensaid, S.; Russo, N.; Fino, D. Appl. Catal. B 2016, 180, 271. doi: 10.1016/j.apcatb.2015.06.018

(32) Liu, F.; Zhao, L.; Wang, H.; Bai, X.; Liu, Y. Int. J. Hydrog. Energy 2014, 39, 10454. doi: 10.1016/j.ijhydene.2014.05.036

(33) Han, X.; Yu, Y. B.; He, H.; Shan, W. P. Int. J. Hydrog. Energy 2013, 38, 10293. doi: 10.1016/j.ijhydene.2013.05.137

(34) Yan, Y.; Yang, Z. Z.; Xu, H. D.; Xu, B. Q.; Zhang, Y. H.; Gong, M. C.; Chen, Y. Q. Acta Phys. -Chim. Sin. 2015, 31, 2358. [杨 怡, 杨铮铮, 徐海迪, 徐宝强, 张艳华, 龚茂初, 陈耀强. 物理化 学学报, 2015, 31, 2358.] doi: 10.3866/PKU.WHXB201510135

(35) Lin, Y. C. Int. J. Hydrog. Energy 2013, 38, 2678. doi: 10.1016/j. ijhydene.2012.12.079 